\title{
ポリマーの劣化挙動のマルチスケールモデリング
}

\section{Multi-scale modeling of degradation behavior for polymer}

\section{○工藤 正和・旭化成}

Masakazu Kudo, Asahi-Kasei Corp.

\author{
高橋 順一・旭化成
}

山本 敏治・旭化成
Toshiharu Yamamoto, Asahi-Kasei Corp.

\section{内田 真・大阪市立大}

Makoto Uchida, Osaka City Univ.
Junichi Takahashi, Asahi-Kasei Corp.

\section{冨田 佳宏・神戸大}

Yoshihiro Tomita, Kobe Univ.

Key Words: Polymer, Degradation, Coarse-grained molecular dynamics, Multi-scale, Interlamellar structure, Craze

\section{1. 緒 言}

近年, ポリマーは材料の改質, 複合化により構造部材とし ての利用が拡大し，それに伴い，長期に渡り機械的機能を維 持することも重要な特性となってきている. しかしながら， ポリマーの劣化のメカニズムは必ずしも明確ではなく, 部材 強度の経時変化は, 部品ごとに使用環境を想定した促進劣化 試験を行って評価するのが現状である.ポリマーの巨視的な 物性は, 微視的な構造と密接に関連しているため, 経年劣化 による微視的構造変化から巨視的な物性変化を予測するこ とが出来れば，産業上極めて有用である.

そこで本研究では, 結晶性ポリマーの劣化による分子構造 変化を粗視化分子動力学によりモデル化し，マルチスケール モデリングを行うことにより劣化が巨視的な力学的応答に 与える影響について検討したので報告する．

2. 劣化による微視構造变化のシミュレーション

結晶性ポリマーは微視的にはラメラ構造をとるため, 8. $3 \mathrm{~nm} \times 8.3 \mathrm{~nm} \times 14.6 \mathrm{~nm}$ の直方体セル内に周期境界条件を与 え, OCTA ${ }^{(1)}$ の Lame1la Generator 機能によりセル内に分子鎖 を発生させることによりラメラ初期構造を再現した. 分子鎖 は, 直鎖状ポリエチレンを仮定し, $\left[\mathrm{C}_{2} \mathrm{H}_{4}\right]_{3}$ の原子団を 1 つの

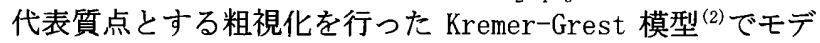
ル化した．質点間のつながりを表す結合ポテンシャル $U_{b o n d}$ は FENE+LJ ポテンシャル(2)を使用した.

$$
\begin{gathered}
U_{\text {bond }}=U_{F E N E}+U_{L J} \\
U_{F E N E}=\left\{\begin{array}{c}
-\frac{1}{2} k R_{0}^{2} \ln \left[1-\left(\frac{r}{R_{0}}\right)^{2}\right], \text { if } r<R_{0} \\
\infty, \text { if } r \geq R_{0}
\end{array}\right. \\
U_{L J}=\left\{\begin{array}{cc}
4 \xi\left[\left(\frac{\delta}{r}\right)^{12}-\left(\frac{\delta}{r}\right)^{6}+\frac{1}{4}\right], & \text { if } r<2^{1 / 6} \delta \\
0, & \text { if } r \geq 2^{1 / 6} \delta
\end{array}\right.
\end{gathered}
$$

ここで $U_{F E N E}$ は分子鎖伸長時の有限長さを表現するための引 力項で, $U_{L J}$ は分子の衝突を避けるための斥力を表現する項で ある. $k$ はバネ定数, $r$ は質点間距離, $R_{0}$ は最大バネ長であ $\eta, \delta, \xi$ 梳献ジョーンズのパラメータである.

結合していない質点間の相互作用（非結合ポテンシャル）は レナードジョーンズポテンシャルを使用した.

$$
U_{\text {nonbond }}=\left\{\begin{array}{cl}
4 \bar{\xi}\left[\left(\frac{\bar{\delta}}{\bar{r}}\right)^{12}-\left(\frac{\bar{\delta}}{\bar{r}}\right)^{6}\right]+U_{\text {cutoff }}, & \text { if } \bar{r}<r_{c} \\
0 & , \text { if } \bar{r} \geq r_{c}
\end{array}\right.
$$

質点間の相互作用は有限範囲とし, カットオフ距離 $r_{c}$ 以上の 引力計算を打ち切り, カットオフ距離でポテンシャルが $0 に$ なるように補正項 $U_{\text {cutoff }}$ を加えた. 解析に使用したポテンシ ヤルパラメータを表 1 に示す。

Table 1 Potential parameters for polyethylene model.

\begin{tabular}{c|c}
\hline$k\left[\mathrm{~kJ} /\left(\mathrm{mol} / \mathrm{nm}^{2}\right)\right]$ & $2.76 \times 10^{3}$ \\
$R_{0}[\mathrm{~nm}]$ & 0.72 \\
$\delta, \bar{\delta}[\mathrm{nm}]$ & 0.52 \\
$\xi, \bar{\xi}[\mathrm{kJ} / \mathrm{mol}]$ & 24.9 \\
$r_{c}[\mathrm{~nm}]$ & 0.68 \\
\hline
\end{tabular}

分子鎖 1 本は直列に結合した 1800 個の質点で表現し（分子 量換算で $\left.M=1.5 \times 10^{5}\right)$, 分子鎖 4 本をセル中に発生させた. ラメラのC 軸方向の結晶相長さを $7.3 \mathrm{~nm}$, 非晶相長さを $7.3 \mathrm{~nm}$ とし, 結晶相, 非晶相の密度はそれぞれ $1.0,0.855 \mathrm{~g} / \mathrm{cm}^{3}$ に設 定した. 図 1 に作成したラメラ構造のモデルを示す.

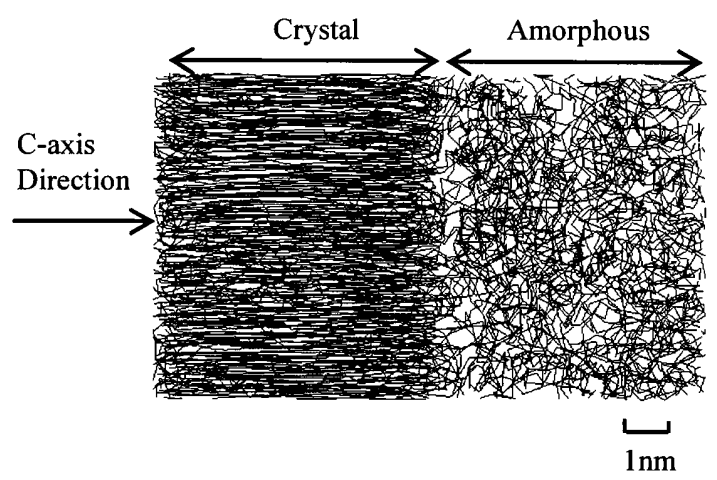

Fig1. Snapshot of initial lamella structure

結晶性ポリマーの劣化機構は, ラメラ構造の非晶部に酸素 が拡散し，酸化反応を起こすことで，分子鎖の切断および架 橋による結合がもたらされると考えられている(3). したがっ て, 図 1 のラメラモデルの非晶部で分子鎖の切断と結合をラ ンダムに与えることで, 劣化を表現することとした. 劣化状 態は, 表 2 に示す無添加ポリエチレンの紫外線劣化による分 子量変化 ${ }^{(4)}$ を参考に, 重量平均分子量 $M_{w}$ が紫外線暴露 50 時 間と 200 時間に相当するように非晶部の分子鎖の切断・結合 を与えることで劣化を定義した。このようにして作成した劣 化の微視構造モデルに C 軸方向にひずみ速度 $3.76 \times 10^{9} \mathrm{~s}^{-1}$ の 伸長変形を与えて延伸時の変形挙動を観察した. 図 2 に歪 1.0 の各劣化段階の伸長変形のスナップショットを示す. 
Table 2 Changes in $M_{w}$ of UV-irradiated polyethylene ${ }^{(4)}$ \begin{tabular}{c|c|c|c} 
UV exposure time $[\mathrm{h}]$ & 0 & 50 & 200 \\
\hline$M_{w}$ & $1.5 \times 10^{5}$ & $2.3 \times 10^{5}$ & $1.3 \times 10^{5}$
\end{tabular}

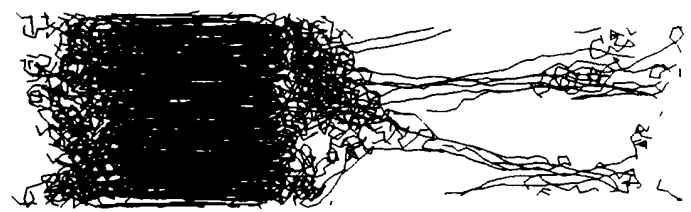

(a)No degradation (Correspond to UV exposure $0 \mathrm{hr}$ )

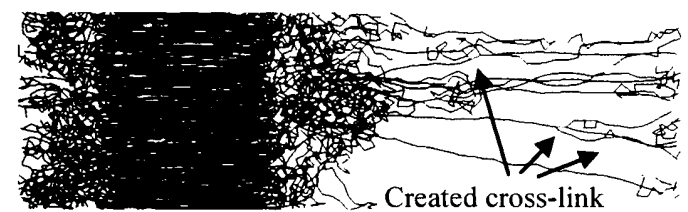

(b)Middle degradation (Correspond to UV exposure 50hr)

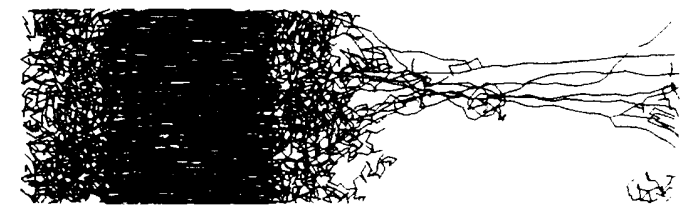

(c)Severe degradation (Correspond to UV exposure 200hr)

Fig2. Snapshots of elongation process of lamella structure at $\varepsilon=1.0$

延伸により，非晶部の分子鎖が引き伸ばされ，延伸方向に 配向したフィブリルとボイドが形成されているのが確認で きる.これは結晶性ポリマーの破壊過程で観察されるクレイ ズの様相に類似している. 紫外線暴露 50 時間相当の場合は, $M_{w}$ が増加するため, 架橋反応が優位に起こっており, 非晶 相の分子間に新たに形成された結合が結晶間の力の伝達を 担っていることがわかる. 紫外線暴露 200 時間相当では, $M_{w}$ が大きく低下し，分子鎖切断が優位となる．結晶間を結 ぶブリッジ鎖の本数が減少しており, 図示はしていないが, 結晶相からの分子鎖の引き抜きも起こるため, クレイズ強度 が低下する。

\section{3. 劣化のマルチスケールモデリング}

劣化の微視構造シミュレーションから,ボイドの生成状況 の違いに着目し, 高橋ら ${ }^{(5)}$ の提案したクレイズ発展式を用い て巨視的な機械的物性の予測を試みた。 簡単のため, ひずみ 速度依存性は考慮しないこととすると, 高橋らの提案したク レイズ進展速度式は式(5)のように単純化できる.

$$
\dot{\omega}=\frac{A}{4}\left[1+\tanh \left\{-D_{3}\left(\bar{\varepsilon}^{p}-\varepsilon_{c}\right)\right\}\right] \dot{\bar{\varepsilon}}^{p}
$$

$\overline{\boldsymbol{\varepsilon}}^{p}$ は相当塑性ひずみ， $\dot{\bar{\varepsilon}}^{p}$ は相当塑性ひずみ速度である. $\varepsilon_{c}$ は成長停止ひずみで, 式(5)はクレイズが一定のひずみ以上で 成長速度が小さくなることを表現している． $A, D_{3}$ は無次元 材料定数で, それぞれクレイズの成長速度の大きさとクレイ ズ成長速度の鈍化具合を表している.

本研究では, クレイズ密度の増加をボイド率の増加と捉え, 粗視化分子動力学から, 図 3 に示す相当塑性ひずみ $\bar{\varepsilon}^{p}$ とボ イド率 $\omega$ の関係を求めた。紫外線暴露時間が長くなるほどク レイズの成長速度が速くなる傾向を示し，特に暴露 200 時間 ではその傾向が顕著である. 図 3 の結果から(5)式でフィッテ イングを行い, クレイズ進展速度式の各パラメータを同定し た結果を表 3 に示す. 同定したパラメータを用いて平板の単 軸引張シミュレーションを行い, 巨視的な力学特性の変化を 確認した. クレイズ発展式以外の条件は, 高橋らの文献 ${ }^{(5)}$ で
例示されているポリプロピレンの条件と同様とした. 破断判 定はクレイズ密度(ボイド体積分率)で行い，限界クレイズ密 度を 0.6 とした. 但し, 紫外線暴露 200 時間の場合は, 相当 塑性ひずみ 0.9 で結晶間を結ぶブリッジ鎖がほぼ消失し，荷 重伝達がなくなるため, そのときのボイド率 0.4 を限界クレ イズ密度とした. 図 4 にシミュレーションの結果得られた破 断ひずみと紫外線暴露時間の関係を示す. 紫外線暴露時間の 増加に伴い, 破断ひずみが減少する実験の傾向 ${ }^{(6)}$ を再現する 結果が得られた。

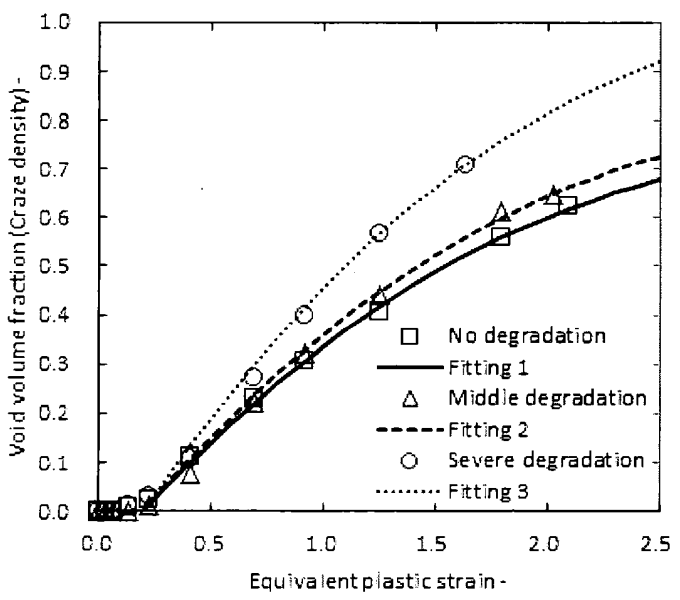

Fig3. Relationship between void volume fraction and equivalent plastic strain.

\begin{tabular}{c|c|c|c} 
Table 3 & \multicolumn{3}{|c}{ Craze parameters } \\
& $A$ & $D_{3}$ & $\varepsilon_{\mathrm{c}}$ \\
\hline (1)No degradation & 1.4 & 0.5 & 1.0 \\
(2)Middle degradation & 1.5 & 0.5 & 1.0 \\
(3)Severe degradation & 1.9 & 0.5 & 1.0 \\
\hline
\end{tabular}

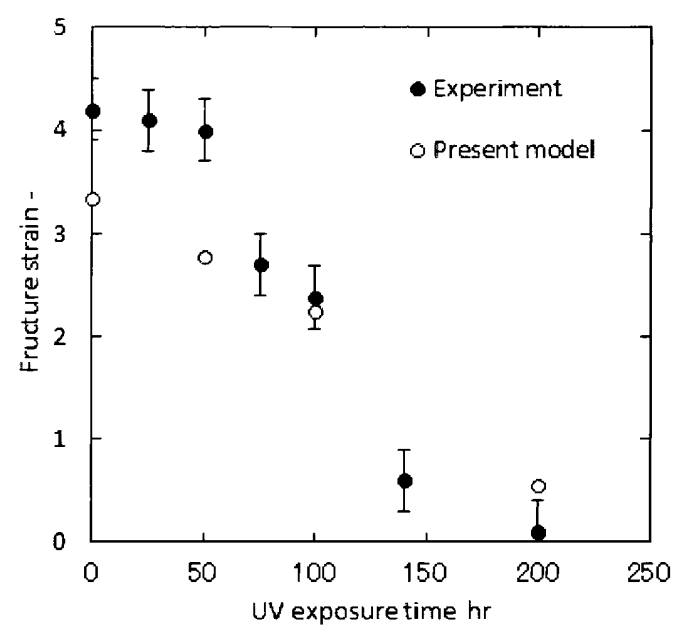

Fig4. Relationship between fracture strain and UV exposed time.

(1) http://octa.jp

\section{文 献}

(2) K. Kremer, G. S. Grest, J. Chem. Phys., 92, 5057 (1990)

(3)大澤, 高分子劣化・長寿命化ハンドブック, 丸善出版

(4)海老沢 - 星野 - 佐藤, 高分子論文集, 36, 791 (1979)

(5)高橋・山本 · 志澤, 機論, 76, 473 (2010)

(6)海老沢 - 星野・佐藤, 高分子論文集, 35, 429 (1978) 